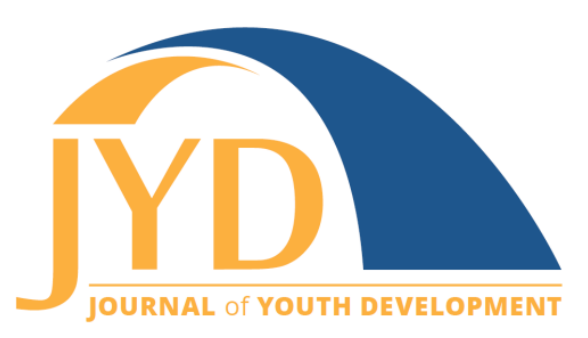

http://jyd.pitt.edu/ | Vol. 15 Issue 1 DOI 10.5195/jyd.2020.817 | ISSN 2325-4017 (online)

\title{
Understanding Youth Worker Job Stress
}

\section{Anne M. White}

St. Vincent College

annie.mcnamara@stvincent.edu

\author{
Alexandra DeMand \\ Child Trends \\ alex.demand@gmail.com

\section{Gina McGovern} \\ University of Illinois, Urbana-Champaign \\ ginam2@illinois.edu
}

\section{Thomas Akiva}

University of Pittsburgh

tomakiva@pitt.edu

\begin{abstract}
Work in out-of-school learning programs can be stressful, and job stress may have cascading effects for the children and youth that attend. Fortunately, workplace supports can help decrease this stress. In this study, we aimed to understand how youth workers' personal and work-related demands as well as supports predict on-the-job stress. We used multilevel modeling to investigate the demands and supports of a sample of 111 youth workers nested in 25 programs. Results suggested that job stress systematically varies at the program level. We found that stress at home and a negative staffing climate is associated with higher stress and the presence of supervisor support is associated with lower staff stress. Supervisor support, in particular, likely can play a key role in decreasing youth worker stress. We discuss implications for training supervisors and structuring programs to support staff and to ultimately foster more positive out-of-school program experiences for the children and youth that attend.
\end{abstract}

Key words: out-of-school learning, youth work, stress

Human-serving professions such as education, social work, and youth work can be stressful. This work often requires emotional labor, or the regulation of one's own stress and emotions

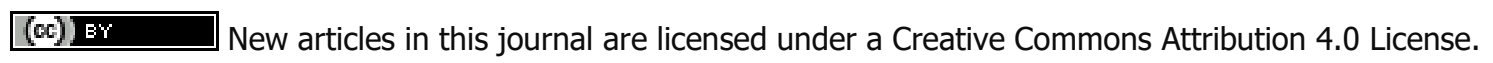
This journal is published by the University Library System, University of Pittsburgh and is cosponsored by the University of Pittsburgh Press. The Journal of Youth Development is the official peer-reviewed publication of the National Association of Extension 4-H Youth Development Professionals and the National AfterSchool Association. 


\section{Understanding Youth Worker Job Stress}

while giving of oneself to others (Pugliesi, 1999). Imagine an adult after-school leader who stops everything she is doing to help a child work through a conflict with a friend-that educator must leave her own challenges "at the door" to listen and respond to the child. Though human-serving occupations can be fulfilling, the emotional labor required can result in high stress, burnout, and turnover (e.g., Kim, 2011). Additionally, the stress of these professions can have cascading impacts on children and youth. For example, job stress can decrease the use of educator practices that support healthy development (Corrigan, Steiner, McCracken, Blaser, \& Barr, 2001; Donat \& McKeegan, 1997), lower the quality of adult-child relationships (Pinderhughes, Bates, Dodge, Pettit, \& Zelli, 2000), and increase burnout and attrition (Font, 2012). At best, staff stress may limit opportunities available for children and, at worst, stress can lead to negative consequences for a child's future trajectory. Supervisor supports and a positive work environment can help decrease the potential negative effects of stress (Boyas, Wind, Ruiz, 2013; Maslach, Schaufeli, \& Leiter, 2001).

In out-of-school learning ${ }^{1}$ (OSL) settings, staff encounter particular challenges that may affect their stress. We define OSL as structured, supervised programs occurring outside of the formal school day, offering a diverse array of activities (e.g., physical activity, homework help, leadership development; Vandell, Larson, Mahoney, \& Watts, 2015). The work of adult leaders in OSL is complex and may take a physiological or psychological toll on staff. Larson and Walker (2010) described OSL work challenges as "dilemmas of practice," which include tasks such as facilitating activities, managing conflict among youth, and completing administrative tasks often with limited resources or training. The authors state that the difficulty of these dilemmas is the "ambiguity, subjectivity, and dependence on judgment" required (Larson \& Walker, 2010, p. 347).

Youth worker job stress can have implications for children. Although little research exists that investigates workplace stress for OSL staff, limited research in education provides relevant findings. Research has shown that teacher stress can predict negative teacher-student relationships (Yoon, 2002) and affect teachers' irritability with students (Shernoff, Mehta, Atkins, Torf, \& Spencer, 2011). Teacher stress has also been associated with students' development of executive functioning skills (Neuenschwander, Friedman-Krauss, Raver, \& Blair, 2017) and learning motivation (Pakarinen et al., 2010). One study showed an association

\footnotetext{
${ }^{1}$ We use "out-of-school learning" instead of the more common "out-of-school time" to capture the goals of positive learning and development supported by most programs in this context.
} 


\section{Understanding Youth Worker Job Stress}

between lower teacher stress and higher student empathy and reduced disruptiveness as well as an association between higher teacher stress and student impulsivity and low cooperation (Siekkinen et al., 2013). Although high-quality OSL programs have been shown to be environments where children and youth can gain valuable social and emotional skills (Durlak \& Weissberg, 2013), OSL staff with high levels of stress may not be emotionally available to support children's development effectively.

Fortunately, organizational supports may help ameliorate stress associated with the demands of OSL work. Researchers find that supportive supervisors can buffer the effects of stress, thereby decreasing burnout (Boyas et al., 2013; Maslach, Schaufeli, \& Leiter, 2001). When employees perceive that their supervisors care about their emotional well-being, they are, on average, more motivated and committed to their job (Rhoades \& Eisenberger, 2002). Additionally, when organizations make investments in employees through professional development, it signals to employees that they are valued, which can promote job satisfaction and effectiveness (Whitener, 2001).

In this study, we investigate workplace stress for youth workers in OSL programs. In particular, we use the Job Demands-Resource model (JD-R; Demerouti, Nachreiner, Bakker, \& Schaufeli, 2001) as a way to consider contributors to stress and supports at the personal and organizational levels. We aim to understand how workplace stress affects the OSL workforce and to examine the supports that may decrease stress with the ultimate goal of benefiting the children and youth that attend programs.

\section{Job Demand-Resource Model}

The JD-R model, a theoretical frame through which to understand worker stress (Demerouti et al., 2001), has been successfully applied across several contexts including education and healthcare. Across multiple studies, researchers find that job demands are associated with stress (e.g., Boyas \& Wind, 2010; Hakanen, Bakker, \& Schaufeli, 2006; Hu, Schaufeli, \& Taris, 2011; Lizano \& Mor Barak, 2012) and job resources can buffer the effect of demands on burnout (e.g., Bakker, Demerouti, \& Euwema, 2005; Boyas et al., 2013). The JD-R model will allow us to investigate job stress and organizational resources in the OSL context.

In the JD-R model, demands are conceptualized as job features that require sustained effort and are considered a "cost" to the employee. Demands can become stressors when high effort 


\section{Understanding Youth Worker Job Stress}

is required without support to meet demands. Employment in OSL settings may place high demands on staff. OSL staff tend to receive less formal training than other youth-serving fields and jobs are often part-time with low wages (Dennehy \& Noam, 2005; Deutsch, Blyth, Kelley, Tolan, \& Lerner, 2017). Some programs compensate staff only for "face time" with children, which may result in staff preparing activities or attending professional development outside of paid work hours (Raley, Grossman, \& Walker, 2005). Personal stressors are also considered demands in the JD-R model (Schaufeli \& Taris, 2013). Research shows that an individual's stressors in one role (i.e., work, home) can increase the effects of stress in their other professional roles (Byron, 2005; Ford, Heinen, \& Langkamer, 2007). This is sometimes referred to as a "spillover" effect, which may play a particularly strong role for OSL staff stress. OSL careers require intense emotional labor. Staff must ignore or regulate their own stress while giving of themselves to the children and youth with whom they work (Pugliesi, 1999). Also, the demographic makeup of OSL staff tends to be majority female (Yohalem, Pittman, \& Moore, 2006). Though gender effects may play less of a role in worker stress than previously believed (Byron, 2005), some research shows that women have home responsibilities that could disproportionately affect the stress they bring into the workplace compared to men (Ford et al., 2007). This is especially true when women have their own children or when their workplaces are not flexible (Byron, 2005).

Resources, on the other hand, refer to aspects of a job (e.g., material or psychological supports) that reduce job demands and stimulate personal growth (Schaufeli \& Bakker, 2004). These can be especially impactful in decreasing stress when demands are high, as in OSL programs (Bakker \& Demerouti, 2007). The support that staff perceive from supervisors may ameliorate the demands of a particular workplace. One hypothesis is that supervisors "buffer" job demands and decrease the consequences of job stress (Babin \& Boles, 1996; Maslach et al., 2001). This buffering effect is associated with decreased burnout and greater job satisfaction (Maertz et al., 2007; Maslach et al., 2001; Rhoades \& Eisenberger, 2002). Supervisors may also create a culture where staff feel psychologically safe by using positive staffing practices (Carmeli \& Gittell, 2009; May, Gilson, \& Harter, 2004). For example, supervisors and organizations that display concern for employees' needs and foster their skill development may enhance employee self-determination and interest in their work as well as a sense of belonging among staff at the organization (Deci, Connell, \& Ryan, 1989; Huang \& Cho, 2010). Program financial resources may also play a role in countering job demands, though there is little research in this area. A 1993 study by the U.S. Department of Education cited common OSL 


\section{Understanding Youth Worker Job Stress}

program expenditures as salaries, benefits, rent, utilities, insurance, and other program costs (Seppanen, 1993).

\section{The Current Study}

In this study, we investigate the effects of individual and job demands and resources on OSL staff stress. In particular, we are interested in teasing out the sources of stress and supports that can be addressed through organizational or field-wide action. First, we hypothesize that perceived stress varies by OSL program due to differences in the organizational context and supports provided by supervisors. Multilevel models allow us to examine the ratio of job stress by program site versus individual. We then address our primary question: How do youth workers' personal and program demands and supports predict on-the-job stress? Based on previous research in related fields, we anticipate that individual sources of stress will be the strongest predictors; however, we hypothesize that supervisor support will be an important predictor of decreased staff stress.

\section{Methods}

\section{Participants}

The data for this study come from the baseline wave of a randomized controlled trial study of a professional development intervention. Prior to the intervention, directors of OSL programs in a mid-sized Midwestern city applied to participate and receive professional development at no cost. Eligible programs served children in preschool through eighth grade in the 2015-2016 school year. Prior to randomization, staff completed surveys via an online link and, when necessary, were provided with hard copies to increase participation.

As indicated in Table 1, 111 OSL staff across 25 programs are included in this study. The sample of staff in programs is predominantly female and identifies as $82 \%$ White and $18 \%$ Black or African American. The average age is slightly over 22 years and many have completed either professional certifications (31\%) or a bachelor's degree (20\%). More than a third report having been at their program less than a year. The average program has 4.5 staff members and the programs serve an average of 38 children daily. The programs serve mostly elementary-aged children and $72 \%$ of program directors reported that a majority of the youth they served were from families at or below the poverty line. 
Journal of Youth Development | http://jyd.pitt.edu/ | Vol. 15 Issue 1 DOI 10.5195/jyd.2020.817 Understanding Youth Worker Job Stress

Table 1. Sample Demographics of Staff $(N=111)$

\begin{tabular}{|c|c|c|}
\hline Characteristic & Count & $\%$ \\
\hline \multicolumn{3}{|l|}{ Gender } \\
\hline Female & 82 & $74 \%$ \\
\hline Male & 29 & $26 \%$ \\
\hline \multicolumn{3}{|l|}{ Race } \\
\hline White & 91 & $82 \%$ \\
\hline Black or African American & 20 & $18 \%$ \\
\hline \multicolumn{3}{|l|}{ Education level } \\
\hline No post-secondary education & 22 & $20 \%$ \\
\hline $\begin{array}{l}\text { Post-secondary (including partial college and associates/ } \\
\text { professional certificates) }\end{array}$ & 59 & $54 \%$ \\
\hline Did not respond & 30 & $27 \%$ \\
\hline \multicolumn{3}{|l|}{ Tenure at program } \\
\hline$<1$ year & 42 & $38 \%$ \\
\hline More than 1 year but $<5$ & 50 & $46 \%$ \\
\hline More than 5 years & 16 & $14 \%$ \\
\hline Did not respond & 3 & $2 \%$ \\
\hline \multicolumn{3}{|l|}{ Age of staff in years } \\
\hline Range & $18-64$ & \\
\hline Mean & 22.29 & \\
\hline SD & 11.14 & \\
\hline
\end{tabular}

\section{Staff Measures (Level-1)}

Our multi-level model uses measures of job stress, demands, and resources for OSL staff at Level-1 and OSL programs at Level-2, as shown in Figure 1. The full measures are provided in Appendix A. 
Figure 1. Program and Individual Demands and Resources

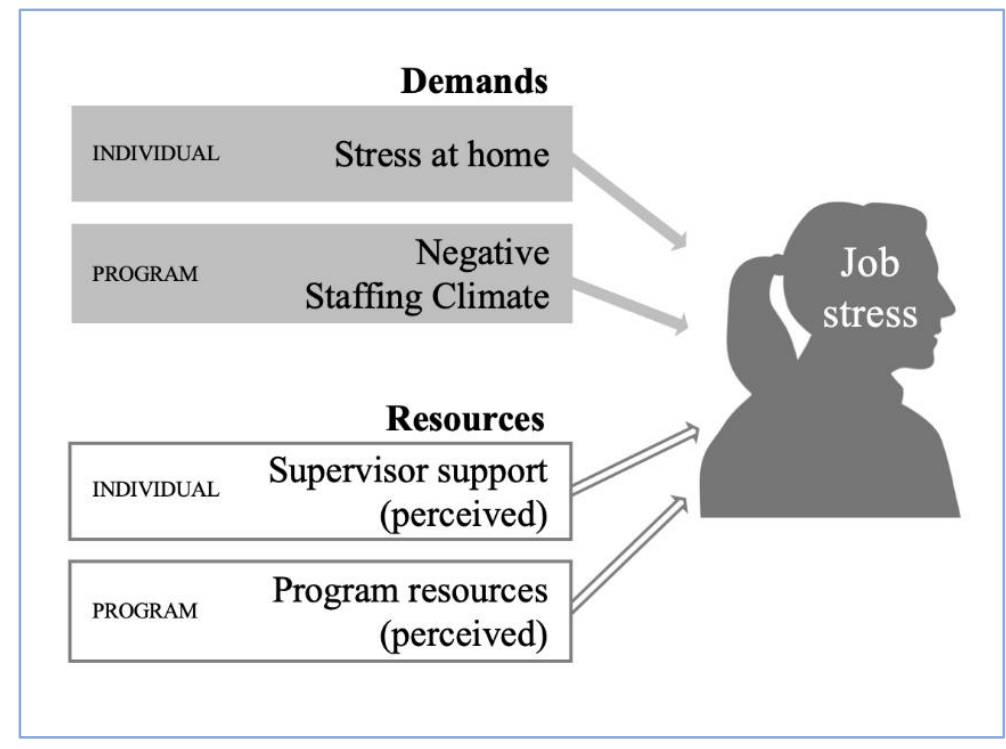

Job Stress

The dependent variable for this study, subjective job stress, includes four questions adapted from Motowidlo, Packard, and Manning (1986) that capture the work stress perceived by OSL staff. Responses are on a 5-point scale of "Strongly Agree" to "Strongly Disagree," e.g., "My job is extremely stressful." ( $a=0.87)$.

\section{Stress at Home}

This four-item scale, developed by Grzywacz \& Marks (2000) explores experiences at home that may affect work. Responses range from "Never" to "Always"; e.g., "Stress at home makes you irritable at work." ( $a=.83)$.

\section{Supervisor Support}

This five-item scale, created by Smith, Akiva, Sugar, \& Hallman (2012), assesses the extent to which a staff member perceives receiving support from their supervisor. Items are on a 5-point scale from "Never" to "At least weekly," e.g., "My supervisor gives me helpful feedback about how I work with youth." $(a=.90)$.

\section{Control Variables}

At Level-1, we controlled for the following staff-reported variables: race: 1 (Black) or 0 (nonBlack); gender: 1 (female) or 0 (male); age in years (continuous variable); tenure working at 
the current program ranked from 1 (less than 1 year) to 7 ( 5 or more years); and education level ranked from 1 (no high school diploma) to 7 (doctoral degree).

\section{Program Measures (Level-2)}

\section{Negative Staffing Climate}

We adapted a measure developed by Smith et al. (2012), which captures practices experienced by staff at a particular program. The five items were ranked on a 5-point response scale ranging from "Never or almost never true of staff" to "Always or almost always true of staff", e.g., "Staff do not have enough time to attend meetings or do planning." ( $a=.80)$.

\section{Perceived Program Resources}

Staff were asked a series of four questions to capture beliefs about their program having enough resources to meet their day-to-day needs. Items were asked on a 5-point scale ranging from "Never" to "Always", e.g., "We have plenty of supplies, materials, and financial support for the activities and projects we want to with kids here." ( $a=.82$ ).

Table 2. Descriptive Statistics of Staff and Program Characteristics

\begin{tabular}{|l|c|c|c|c|c|}
\hline Staff Characteristics $(\boldsymbol{N}=\mathbf{1 1 1})$ & Mean & SD & Range & Skew & Kurt \\
\hline Age of staff in years & 22.29 & 11.14 & $18-64$ & & \\
\hline Supervisor Support & 4.08 & 0.89 & $1.3-5$ & -0.97 & 2.26 \\
\hline Stress at home & 1.93 & 0.63 & $1-3.3$ & 0.04 & 2.05 \\
\hline & & & & & \\
\hline Program Characteristics $(\mathbf{N}=\mathbf{2 5})$ & Mean & SD & Range & Skew & Kurt \\
\hline Negative Staffing Climate & 3.86 & 0.50 & $1.4-4.9$ & 1.00 & 2.8 \\
\hline Program Resources & 3.79 & 0.54 & $1.5-5$ & -0.04 & 2.14 \\
\hline
\end{tabular}

\section{Control Variables}

The program (Level-2) control variable is child socioeconomic status (SES), determined by a program director's estimate of the proportion of children in their particular program that live near or below the poverty line. 
Understanding Youth Worker Job Stress

\section{Data Analysis}

This study explores the relationships presented in Figure 1 , between job demands and resources for OSL staff and their experience of stress. We first used correlations to examine these relationships for all staff, regardless of program. This helped to isolate relationships between the demands, resources, and stress that are explained by differences between individuals. Then we used multilevel modeling, a statistical technique for showing relationships between nested variables (Raudenbush \& Bryk, 2002), to compare the results for OSL staff nested in different programs. This analysis helped us to understand whether there were differences in the relationships among job demands, resources, and stress that are explained by factors at the program level. Further details about the statistical methods and software used can be found in Appendix B.

\section{Results}

\section{Job Stress is Associated With Individual and Program Demands and Resources}

Correlations indicate that staff with higher levels of job stress also reported higher levels of stress at home $(r=0.54)$ and lower supervisor support $(r=-0.42)$. At the program level, we found staff that work at programs with a negative staffing climate and fewer program resources report having higher levels of stress ( $r=0.44$ and $r=-0.34$, respectively). At the program level, more plentiful resources were related to lower reports of negative staffing practices ( $r=$ .59). All correlations are presented in Appendix B.

\section{Job Stress Varies by Program}

Our second set of analyses examined differences between programs. We found that reported job stress significantly varied across the 25 programs in our sample $(\beta=2.91, p<.001)$. The lowest average job score for a program was 1.75 , and the highest was 4.5 . This suggests that there are likely organizational differences in the culture and climate affecting staff job stress.

\section{Individual Experiences of Supervisor Support and Home Stress May Affect Job Stress}

The results of our next set of analyses are summarized in Figure 2, where we have overlaid a plus sign where positive associations between variables were found and a minus sign where negative associations were found. For individuals, we found that stress at home and supervisor 
support significantly predicted job stress. The individual demand of stress at home positively predicted stress $(b=0.60, p<.001)$, such that a 1-unit increase in stress at home is associated with a 0.60 increase in staff stress. We also found a significant negative prediction of job stress by the individual resource, perceived supervisor support $(b=-0.22, p=.01)$, where more support is associated with lower stress after controlling for staffing practices and stress at home. Staff race, gender, age, tenure, and education and SES of children in a particular program were not related to job stress in our analysis so were not included.

\section{Negative Staffing Climate Predicts Job Stress; Resources Do Not}

Negative staffing climate positively predicted job stress and this varied significantly across organizations ( $\mathrm{Y}_{01}=0.45, p=.01$ ). A 1-unit increase in negative staffing climate associated with an increase in job stress by 0.45 units after controlling for stress at home and supervisor support. Program resources was not predictive of staff stress and was dropped from the final model.

Figure 2. Relationships Between Program and Individual Demands and Resources and Stress

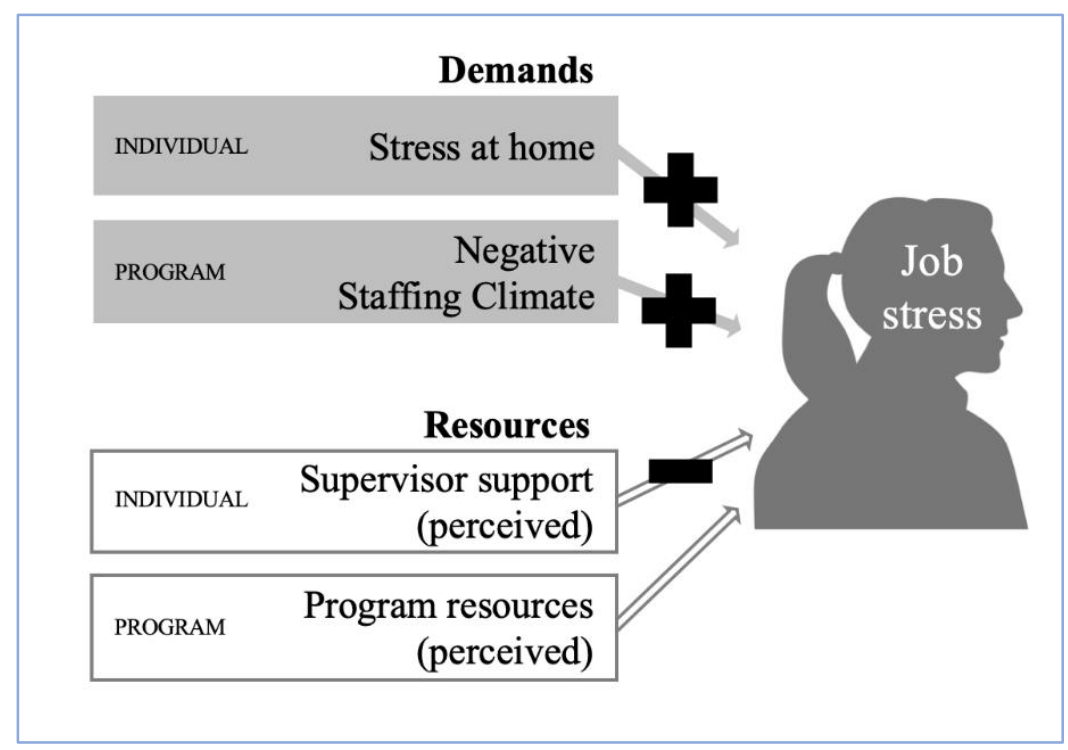

\section{Discussion}

To address our primary research question, how do staff members' and youth programs' demands and supports predict on-the-job stress?, we used hierarchical linear modeling which 


\section{Understanding Youth Worker Job Stress}

accounts for the data structure of staff nested in OSL programs (Raudenbush \& Bryk, 2002). First, we found that job stress appears to systematically vary at the program level. This suggests potential differences in organizational contexts that may affect job stress. Also, consistent with the Job Demands-Resource model and as indicated in Figure 2, we found that the individual demand of stress at home and the program-level demand of a negative staffing climate were associated with higher job stress. The individual resource of perceived supervisor support appeared to buffer the effect of demands and was associated with lower staff stress. Program-level resources did not impact job stress in this study. Implications of these findings are described below and summarized in Table 2.

Table 2. Summary of Findings and Implications

\begin{tabular}{|c|c|c|}
\hline & $\begin{array}{l}\text { Relationship to } \\
\text { job stress }\end{array}$ & Implications for program supervisors \\
\hline \multicolumn{3}{|l|}{ Demands } \\
\hline $\begin{array}{l}\text { Individual: } \\
\text { Stress at home }\end{array}$ & + & $\begin{array}{l}\text { - Set time aside to create a community of } \\
\text { practice through which to address challenges. } \\
\text { - Provide professional development for coping } \\
\text { strategies, mindfulness, and stress relief } \\
\text { (Chiesa \& Serretti, 2009; Keng, Smoski, \& } \\
\text { Robins, 2011; Shernoff et al., 2011; Yoon, } \\
\text { 2002). }\end{array}$ \\
\hline $\begin{array}{l}\text { Program: } \\
\text { Negative staffing climate }\end{array}$ & + & $\begin{array}{l}\text { - } \quad \text { Provide a positive working environment and } \\
\text { - } \quad \text { Offer relevant training in youth development. } \\
\text { - } \quad \text { Offer peer mentoring and learning communities } \\
\text { - } \quad \text { (Raley et al., 2005; Wanless \& Winters, 2018). }\end{array}$ \\
\hline \multicolumn{3}{|l|}{ Resources } \\
\hline $\begin{array}{l}\text { Individual: } \\
\text { Supervisor support (perceived) }\end{array}$ & - & $\begin{array}{l}\text { - } \quad \text { Provide regular supervisory check-ins. } \\
\text { - } \quad \text { Provide asset-based feedback. } \\
\text { - } \text { Offer time for reflective practice } \\
\text { - } \quad \text { (Smith et al., 2012). }\end{array}$ \\
\hline $\begin{array}{l}\text { Program: } \\
\text { Program resources (perceived) }\end{array}$ & None & \\
\hline
\end{tabular}




\section{Understanding Youth Worker Job Stress}

\section{Individual Demands}

Stress at home was the strongest Individual-level predictor of job stress in our model. It suggests that youth workers may experience a variety of sources of stress at home (e.g., financial, family relationships, etc.) and bring this stress with them into their job. This finding aligns with previous research that shows that stressors in one role (i.e., work, home) are related to stress experienced in other roles (Ford et al., 2007). In addition, previous research shows that when individuals are expected to ignore stress spillover from other contexts, it can cause more stress (Hobfoll \& Shirom, 2001; Pugliesi, 1999).

In OSL programs, it may be useful for supervisors to set aside time for staff to work through challenging situations they may face both in and out of the workplace as a community of practice. By providing a space for staff to acknowledge demands on their time, they may be able to be more present when working with children (e.g., Shernoff et al., 2011; Yoon, 2002). Also, professional development opportunities related to coping strategies, mindfulness, stress relief, as well as enhancing social and emotional skills of staff may be beneficial. For example, many studies document the relationship between using mindfulness strategies and decreased stress (e.g., Chiesa \& Serretti, 2009; Keng et al., 2011).

\section{Program Demands}

We found that the organizational demand of negative staffing climate was associated with staff job stress. Organizations that offer consistent and high-quality professional development may see benefits of lower job stress among staff (Sabo Flores, 2007). Professional development can increase staff efficacy and feelings of competency (Akiva, Li, Martin, Galetta \& McNamara, 2016; Duran \& Duran, 2005) and site-level staff meetings can serve to mentor new staff, build rapport among team members, and foster collaboration (Huang \& Cho, 2010). Raley and colleagues (2005) suggest several strategies that may relate to staff retention, an indicator of decreased staff stress. The first strategy they offer is hiring the right staff-those with the passion and skills that are a good match with the organizational goals and for working with young people. Second, organizations that align staff members' interests and skills with the tasks for which they are responsible are more likely to retain their staff. Third, organizations can offer job-relevant training in child development, curriculum planning, and group management, though this recommendation raises two challenges-paying for training and scheduling a convenient time to offer the training. Finally, organizations can offer daily staff development 
through supervisory support, peer mentoring, or the creation of learning communities (Raley et al., 2005).

\section{Individual Resources}

One individual resource that may ameliorate OSL staff stress is supervisor support. Our findings align with previous research showing that supervisor support may reduce demands and workplace stress (Bakker \& Demerouti, 2007). Additionally, staff that feel supported by their supervisors may experience a positive spillover from work to other parts of their lives (Grzywacz \& Marks, 2000). Some research shows that perceptions of receiving support may influence mental health as much as the actual support given (Dunkel-Schetter \& Bennett, 1990; Thoits, 1991). An important implication is that organizations can implement routines to support staff needs. For example, professional development opportunities or regular supervisor check-ins may help reduce job stress (Langhout, Rhodes, \& Osborne, 2004). In addition, our findings have implications for training supervisors and directors of programs. There may be strategies supervisors can learn to actively listen to and support their staff. Research shows that using strengths-based language, giving positive feedback, and offering time for reflective practice can create a psychologically safe work environment (Akiva et al., 2016; Wanless \& Winters, 2018). This may help to cultivate a work environment that is safe and positive for staff, thereby decreasing stress and enhancing positive relationships between staff and children.

\section{Program Resources}

Finally, we found a correlation between programs with adequate organizational financial resources and less staff stress; however, this relationship was not significant in our regression models. It may be that lower resources may associate with job stress but that factors like supervisor support and the staff climate are more proximal or experienced more directly and may lessen the relationship between those variables. This finding does not suggest that OSL programs are adequately funded, or that staff are consistently fairly compensated for their work. This finding suggests, however, that by providing support and changing OSL systems, program supervisors may be able to influence staff stress.

\section{Limitations and Future Research}

Although this study contributes to our understanding of OSL staff stress, we acknowledge limitations and areas for future research. First, this study is cross-sectional, from a single wave 


\section{Understanding Youth Worker Job Stress}

of data collection, and therefore, we can make claims only about associations between staff experiences and job stress. In addition, the measures we used may not capture all of the important aspects of personal and organizational demands and resources affecting OSL staff. These phenomena can be operationalized in a multitude of ways, and the variables available to us in this particular study may have excluded demands or resources relevant to OSL staff's experience. Future research could explore additional dimensions of OSL staff stress. For instance, we might learn about more strategies to decrease youth worker stress by investigating the association between job commitment or job satisfaction and stress. Additional research could also build on this study's findings that youth workers do experience job stress and that supervisors can play a role in ameliorating staff stress through supportive practices. Additional research is needed to explore the effects of supervisor support on OSL staff stress. Finally, replication of this study in OSL contexts in other rural, suburban, and urban locations around the country would strengthen the results of this study and allow for a comparison of staff stress across contexts.

\section{Implications of Stress in Youth Development}

In the early 2000s, there was concerted effort towards counting, describing, and professionalizing the youth work sector. These investigations reported that there were large numbers of youth workers who were employed part-time and earned low wages with few benefits (Dennehy \& Noam, 2005; Stone, Garza, \& Borden, 2004; The Annie E. Casey Foundation, 2003). Additional challenges included high turnover, inadequate training and preparation, and few opportunities for advancement. Today, there is a lack of research attention on the individuals who work directly with youth. This study illuminates the realities of the stress that youth workers face. Given the conditions described by research from the last decade, this finding is not surprising, but it is concerning. Stressed workers may not be prepared to provide optimal services for youth. Recent work examining the well-being of youth development workers serving low-income and marginalized communities emphasizes the importance of strengthening the skills of this workforce in order to enhance youth development (Cappella \& Godfrey, 2019).

Our findings suggest that OSL organizations and supervisors can play a key role in reducing staff stress. Though supervisors face challenges, such as limited funding or physical resources, there are supports they can provide to their staff. For example, they can offer effective feedback and buffer staff from taking on too many administrative duties that may add stress and distract staff from their jobs (Akiva et al., 2016). Such supports may reduce attrition for 
both frontline and supervisory staff and promote high-quality programs for children and youth in low-resourced communities. Focusing on ameliorating staff stress through supervisor supports may ultimately lead to more positive interactions between adults and the children and youth with whom they work. Finally, though reducing stress may improve workers' daily interactions, the onus should not be solely on the individual. More systemic change that professionalizes the youth development work force and provides more sustainable funding is required.

\section{References}

Akiva, T., Li, J., Martin, K. M., Horner, C. G., \& McNamara, A. R. (2016). Simple interactions: Piloting a strengths-based and interaction-based professional development intervention for out-of-school time programs. Child and Youth Care Forum, 46(3), 285-305. https://doi.org/10.1007/s10566016-9375-9

The Annie E. Casey Foundation. (2003). The unsolved challenge of system reform.

Babin, B. J., \& Boles, J. S. (1996). The effects of perceived co-worker involvement and supervisor support on service provider role stress, performance and job satisfaction. Journal of Retailing, 72(1), 5775. https://doi.org/10.1016/S0022-4359(96)90005-6

Bakker, A. B., \& Demerouti, E. (2007). The job demands-resources model: State of the art. Journal of Managerial Psychology, 22(3), 309-328. https://doi.org/10.1108/02683940710733115

Bakker, A. B., Demerouti, E., \& Euwema, M. C. (2005). Job resources buffer the impact of job demands on burnout. Journal of Occupational Health Psychology, 10(2), 170-180.

\section{https://doi.org/10.1037/1076-8998.10.2.170}

Boyas, J. F., \& Wind, L. H. (2010). Employment-based social capital, job stress, and employee burnout: A public child welfare employee structural model. Children and Youth Services Review, 32(3), 380388. https://doi.org/10.1016/j.childyouth.2009.10.009

Boyas, J. F., Wind, L. H., \& Ruiz, E. (2013). Organizational tenure among child welfare workers, burnout, stress, and intent to leave: Does employment-based social capital make a difference? Children and Youth Services Review, 35(10), 1657-1669.

\section{https://doi.org/10.1016/j.childyouth.2013.07.008}

Byron, K. (2005). A meta-analytic review of work-family conflict and its antecedents. Journal of Vocational Behavior, 67(2), 169-198. https://doi.org/10.1016/j.jvb.2004.08.009

Cappella, E., \& Godfrey, E. B. (2019). New perspectives on the child- and youth-serving workforce in lowresource communities: Fostering best practices and professional development. American Journal of Community Psychology, 63(3-4), 245-252. https://doi.org/10.1002/ajcp.12337 
Carmeli, A., \& Gittell, J. H. (2009). High-quality relationships, psychological safety, and learning from failures in work organizations. Journal of Organizational Behavior, 306), 709-729.

\section{https://doi.org/10.1002/job.565}

Chiesa, A., \& Serretti, A. (2009). Mindfulness-based stress reduction for stress management in healthy people: A review and meta-analysis. Journal of Alternative and Complementary Medicine, 15(5), 593-600. https://doi.org/10.1089/acm.2008.0495

Corrigan, P. W., Steiner, L., McCracken, S. G., Blaser, B., \& Barr, M. (2001). Strategies for disseminating evidence-based practices to staff who treat people with serious mental illness. Psychiatric Services, 52(12), 1598-1606. https://doi.org/10.1176/appi.ps.52.12.1598

Deci, E. L., Connell, J. P., \& Ryan, R. M. (1989). Self-determination in a work organization. Journal of Applied Psychology, 74(4), 580-590. https://doi.org/10.1037/0021-9010.74.4.580

Demerouti, E., Nachreiner, F., Bakker, A. B., \& Schaufeli, W. B. (2001). The job demand-resources model of burnout. Journal of Applied Psychology, 86(3), 499-512. https://doi.org/10.1108/02683940710733115

Dennehy, J., \& Noam, G. G. (2005). Evidence for action: Strengthening after-school programs for all children and youth: The Massachusetts out-of-school time workforce. Boston, MA: Achieve Boston, an Initiative of Boston After School \& Beyond.

Deutsch, N. L., Blyth, D. A., Kelley, J., Tolan, P. H., \& Lerner, R. M. (2017). Let's talk after-school: The promises and challenges of positive youth development for after-school research, policy, and practice. In N. Deutsch (Ed.), After-school programs to promote positive youth development (pp. 45-68). Cham, Switzerland: Springer. https://doi.org/10.1007/978-3-319-59132-2 4

Donat, D. C., \& McKeegan, G. F. (1997). Behavioral knowledge and occupational stress among inpatient psychiatric caregivers. Psychiatric Rehabilitation Journal, 21(1), 67-69.

Dunkel-Schetter, C., \& Bennett, T. L. (1990). Differentiating the cognitive and behavioral aspects of social support. In B. R. Sarason, I. G. Sarason, \& G. R. Pierce (Eds.), Social support: An interactional view (pp. 267-296). New York, NY: Wiley.

Duran, E., \& Duran, L. B. (2005). Project ASTER: A model staff development program and its impact on early childhood teachers' self-efficacy. Journal of Elementary Science Education, 17(2), 1-12.

Durlak, J. A., \& Weissberg, R. P. (2013). Afterschool programs that follow evidence-based practices to promote social and emotional development are effective. In T. K. Peterson (Ed.), Expanding minds and opportunities: Leveraging the power of afterschool and summer learning for student success (pp. 194-198). Washington, DC: Collaborative Communications Group.

Font, S. (2012). Burnout in child welfare: The role of employment characteristics and workplace opportunities. Social Service Review, 86(4), 636-659. https://doi.org/10.1086/668817 
Ford, M. T., Heinen, B. A., \& Langkamer, K. L. (2007). Work and family satisfaction and conflict: A metaanalysis of cross-domain relations. Journal of Applied Psychology, 92(1), 57-80.

\section{https://doi.org/10.1037/0021-9010.92.1.57}

Grzywacz, J. G., \& Marks, N. F. (2000). Reconceptualizing the work-family inetrface: An ecological perspective on the corelates of positive and negative spliiover between work and family. Journal of Occupational Health Psychology, 5(1), 111-126.

Hakanen, J. J., Bakker, A. B., \& Schaufeli, W. B. (2006). Burnout and work engagement among teachers. Journal of School Psychology, 43(6), 495-513. https://doi.org/10.1016/j.jsp.2005.11.001

Hobfoll, S. E., \& Shirom, A. (2001). Conservation of resources theory: Applications to stress and management in the workplace. In R. T. Golembiewski (Ed.), Handbook of organizational behavior ( $2^{\text {nd }}$ ed., pp. 57-80). New York, NY: Marcel Dekker.

Hu, Q., Schaufeli, W. B., \& Taris, T. W. (2011). The job demands-resources model: An analysis of additive and joint effects of demands and resources. Journal of Vocational Behavior, 79(1), 181190. https://doi.org/10.1016/j.jvb.2010.12.009

Huang, D., \& Cho, J. (2010). Using professional development to enhance staff retention. Afterschool Matters, 12, 9-16.

Keng, S. L., Smoski, M. J., \& Robins, C. J. (2011). Effects of mindfulness on psychological health: A review of empirical studies. Clinical Psychology Review, 31(6), 1041-1056.

\section{https://doi.org/10.1016/j.cpr.2011.04.006}

Kim, H. (2011). Job conditions, unmet expectations, and burnout in public child welfare workers: How different from other social workers? Children and Youth Services Review, 33(2), 358-367. https://doi.org/10.1016/j.childyouth.2010.10.001

Langhout, R. D., Rhodes, J. E., \& Osborne, L. N. (2004). An exploratory study of youth mentoring in an urban context: Adolescents' perceptions of relationship styles. Journal of Youth and Adolescence, 33(4), 293-306.

Larson, R. W., \& Walker, K. C. (2010). Dilemmas of practice: Challenges to program quality encountered by youth program leaders. American Journal of Community Psychology, 45(3-4), 338-349.

Lizano, E. L., \& Mor Barak, M. E. (2012). Workplace demands and resources as antecedents of job burnout among public child welfare workers: A longitudinal study. Children and Youth Services Review, 34(9), 1769-1776. https://doi.org/10.1016/j.childyouth.2012.02.006

Maertz, C. P., Griffeth, R. W., Campbell, N. S., Allen, D. G. (2007). The effects of perceived organizational support and perceived supervisor support on employee turnover. Journal of Organizational Behavior, 28(8), 1059-1075. https://doi.org/10.1002/job.472

Maslach, C., Schaufeli, W. B., \& Leiter, M. P. (2001). Job burnout. Annual Review of Psychology, 52, 397422. 
May, D. R., Gilson, R. L., \& Harter, L. M. (2004). The psychological conditions of meaningfulness, safety and availability and the engagement of the human spirit at work. Journal of Occupational and Organizational Psychology, 771), 11-37. https://doi.org/10.1348/096317904322915892

Motowidlo, S. J., Packard, J. S., \& Manning, M. R. (1986). Occupational stress: Its causes and consequences for job performance. Journal of Applied Psychology, 71(4), 618-629. https://doi.org/10.1037/0021-9010.71.4.618

Neuenschwander, R., Friedman-Krauss, A., Raver, C., \& Blair, C. (2017). Teacher stress predicts child executive function: Moderation by school poverty. Early Education and Development, 28(7), 880900. https://doi.org/10.1080/10409289.2017.1287993

Pakarinen, E., Kiuru, N., Lerkkanen, M. K., Poikkeus, A. M., Siekkinen, M., \& Nurmi, J. E. (2010). Classroom organization and teacher stress predict learning motivation in kindergarten children. European Journal of Psychology of Education, 25(3), 281-300. https://doi.org/10.1007/s10212$\underline{010-0025-6}$

Pinderhughes, E. E., Bates, J. E., Dodge, K. A., Pettit, G. S., \& Zelli, A. (2000). Discipline responses: Influences of parents' socioeconomic status, ethnicity, beliefs about parenting, stress, and cognitive-emotional processes. Journal of Family Psychology, 14(3), 380-400.

https://doi.org/10.1037/0893-3200.14.3.380

Pugliesi, K. (1999). The consequences of emotional labor: Effects on work stress, job satisfaction, and well-being. Motivation and Emotion, 23(2), 125-154. https://doi.org/10.1023/A:1021329112679

Raley, R., Grossman, J., \& Walker, K. E. (2005). Getting it right: Strategies for after-school success. Philadelphia, PA: Public/Private Ventures.

Raudenbush, S. W., \& Bryk, A. S. (2002). Hierarchical linear models: Applications and data analysis methods (Vol. 1). Thousand Oaks, CA: Sage.

Rhoades, L., \& Eisenberger, R. (2002). Perceived organizational support: A review of the literature. Journal of Applied Psychology, 874), 698-714. https://doi.org/10.1037/0021-9010.87.4.698

Sabo Flores, K. (2007). A dynamic framework for understanding the complex work of quality out-ofschool-time programs. New York, NY: The Robert Bowne Foundation.

Schaufeli, W. B., \& Bakker, A. B. (2004). Job demands, job resources, and their relationship with burnout and engagement: A multi-sample study. Journal of Organizational Behavior, 25(3), 293-315. https://doi.org/10.1002/job.248

Schaufeli, W. B., \& Taris, T. W. (2013). A critical review of the job demands-resources model: Implications for improving work and health. In G. F. Bauer \& O. Hämmig (Eds.), Bridging occupational, organizational and public health: $A$ transdisciplinary approach (pp. 43-68). New York, NY: Springer Science+Business Media. 
Seppanen, P. S. (1993). National study of before- and after-school programs: Final report. Portsmouth, $\mathrm{NH}$ : Under contract for the Department of Education by RMC Research Corporation.

Shernoff, E. S., Mehta, T. G., Atkins, M. S., Torf, R., \& Spencer, J. (2011). A qualitative study of the sources and impact of stress among urban teachers. School Mental Health, 3(2), 59-69. https://doi.org/10.1007/s12310-011-9051-z

Siekkinen, M., Pakarinen, E., Lerkkanen, M. K., Poikkeus, A. M., Salminen, J., Poskiparta, E., \& Nurmi, J. E. (2013). Social competence among 6-year-old children and classroom instructional support and teacher stress. Early Education and Development, 24(6), 877-897. https://doi.org/10.1080/10409289.2013.745183

Smith, C., Akiva, T., Sugar, S., \& Hallman, S. (2012). Leading indicators measurement system: Analysis of Oklahoma data - Technical appendix to the Oklahoma $21^{\text {st }}$ century community learning centers statewide evaluation. Ypsilanti, MI: David P. Weikart Center for Youth Program Quality at the Forum for Youth Investment.

StataCorp LP. (2015). STATA Base reference manual (Release 14). College Station, TX: Stata Press. Stone, B., Garza, P., \& Borden, L. M. (2004). Attracting, developing \& retaining youth workers for the next generation. Wingspread Conference Proceedings. Washington, DC.

Thoits, P. A. (1991). On merging identity theory and stress research. Social Psychology Quarterly, 54(2), 101. https://doi.org/10.2307/2786929

Vandell, D. L., Larson, R. W., Mahoney, J. L., \& Watts, T. W. (2015). Children's organized activities. In Handbook of Child Psychology and Developmental Science (pp. 1-40). Hoboken, NJ: John Wiley \& Sons. https://doi.org/10.1002/9781118963418.childpsy408

Vrieze, S. I. (2012). Model selection and psychological theory: A discussion of the differences between the Akaike information criterion (AIC) and the Bayesian information criterion (BIC). Psychological Methods, 172), 228-243. https://doi.org/10.1037/a0027127

Wanless, S. B. \& Winters, D. (2018). A welcome space for taking risks. The Learning Professional, 39(4), 41-44.

Whitener, E. M. (2001). Do "high commitment" human resource practices affect employee commitment? Journal of Management, 275), 515-535. https://doi.org/10.1177/014920630102700502

Woodhouse, G., Yang, M., Goldstein, H., \& Rasbash, J. (1996). Adjusting for measurement error in multilevel analysis. Journal of the Royal Statistical Society. Series A, 159(2), 201-212. https://doi.org/10.2307/2983168

Yohalem, N., Pittman, K., \& Moore, D. (2006). Growing the next generation of youth work professionals: Workforce opportunities and challenges. Washington, DC: Next Generation Youth Work Coalition.

Yoon, J. S. (2002). Teacher characteristics as predictors of teacher-student relationships: Stress, negative affect, and self-efficacy. Social Behavior and Personality, 30(5), 485-494. https://doi.org/10.2224/sbp.2002.30.5.485 


\section{Appendix A: Full List of Measures}

\section{Job Stress}

1. I feel a great deal of stress because of my job.

2. Very few stressful things happen to me at work. $\mathrm{R}$

3. My job is extremely stressful.

4. I almost never feel stressed at work. R

\section{Stress at Home}

1. Responsibilities at home reduce the effort you can devote to your job.

2. Personal or family worries and problems distract you when you are at work.

3. Activities and chores at home prevent you from getting the amount of sleep you need to do your job well.

4. Stress at home makes you irritable at work.

\section{Supervisor Support}

1. My supervisor gives me helpful feedback about how I work with youth.

2. My supervisor is visible during the offerings that I lead or co-lead.

3. My supervisor knows what I am trying to accomplish with youth.

4. My supervisor challenges me to innovate and try new ideas.

5. My supervisor makes sure that program goals and priorities are clear to me.

\section{Negative Staffing Climate}

1. Staff don't stay at our program long.

2. We don't have enough staff and/or student-to-staff ratios are too high.

3. New staff do not get an adequate orientation.

4. Staff do not have enough time to attend meetings or do planning.

5. Staff are not designing and delivering activities consistent with program goals and objectives for students. 


\section{Perceived Program Resources}

1. We struggle to access resources for kids (such as games, art, supplies, books, etc.). R

2. Staff must buy supplies for this program using their own personal money. $R$

3. We have plenty of supplies, materials, and financial support for the activities and projects we want to with kids here.

4. Staff have enough time to do all of their job responsibilities (for example administrative work, activity planning, professional development, and direct work with kids). 


\section{Appendix B: Statistical Analyses}

This study utilizes multilevel modeling, a technique that accounts for "clustering" in the data, to capture the experiences of staff within and across OSL programs (Raudenbush \& Bryk, 2002). To prepare our data for analyses we tested our variables for missing data and for the statistical assumptions of normality and homoscedasticity, all of which were met (refer to Table B1). We conducted our analyses in STATA v.14 using XTMIXED command (StataCorp LP, 2015) and the restricted maximum likelihood estimation method (REML; Woodhouse, Yang, Goldstein, \& Rasbash, 1996). We built our statistical models first by testing the unconditional model, followed by staff level variables then program level variables, and we tested improvements in models using likelihood ratio tests. To measure goodness-of-fit we used Akaike's information criterion (AIC), where decrease in AIC indicates improved model fit (Vrieze, 2012).

Table B1. Correlations Between Stress and Level-1 and Level-2 Predictor Variables

\begin{tabular}{|c|c|c|c|c|c|c|c|c|c|c|}
\hline & $\begin{array}{l}\text { 1. Job } \\
\text { Stress }\end{array}$ & 2 & 3 & 4 & 5 & 6 & 7 & 8 & 9 & 10 \\
\hline \multicolumn{11}{|c|}{ Level 1: Individual staff predictors } \\
\hline 2. Family stress & $.54 *$ & - & & & & & & & & \\
\hline 3. Supervisor support & $-.42 *$ & $-.32 *$ & - & & & & & & & \\
\hline 4. Race $^{a}$ & $.28^{*}$ & $.33^{*}$ & -.11 & - & & & & & & \\
\hline 5. Age & .09 & .04 & -.08 & $.25 *$ & - & & & & & \\
\hline 6. Tenure & .08 & .11 & -.11 & .12 & .09 & - & & & & \\
\hline 7. Gender b & .02 & -.04 & -.09 & .10 & -.16 & -.10 & - & & & \\
\hline 8. Education & .10 & -.05 & -.16 & .07 & $.60^{*}$ & -.10 & -.10 & - & & \\
\hline \multicolumn{11}{|c|}{ Level 2: Program predictors ${ }^{c}$} \\
\hline 9. Negative staffing & $.44 *$ & $.30 *$ & $-.34 *$ & .16 & .18 & -.10 & .11 & .12 & - & \\
\hline 10. Program resource & $-.34 *$ & $-.28 *$ & $.35 *$ & -.14 & -.14 & .00 & -.10 & -.10 & $-.59 *$ & - \\
\hline 11. Child SES & -.08 & -.17 & .05 & -.02 & -.16 & .00 & .20 & -.10 & $-.41 *$ & .09 \\
\hline
\end{tabular}

a Race is coded such that $1=$ Black and $0=$ White, Mixed, or Other

${ }^{\mathrm{b}}$ Gender is coded such that $1=$ Female and $0=$ Male

c Level-1 variables aggregated to program level for these correlations.

$* p \leq .05$ 
Journal of Youth Development | http://jyd.pitt.edu/ | Vol. 15 Issue 1 DOI 10.5195/jyd.2020.817 Understanding Youth Worker Job Stress

Table B2. Multilevel Models Predictive of Staff Stress

\begin{tabular}{|c|c|c|c|}
\hline & $\begin{array}{c}\text { Model 1: } \\
\text { Fully } \\
\text { unconditional }\end{array}$ & $\begin{array}{c}\text { Model 2: } \\
\text { All variables }\end{array}$ & $\begin{array}{c}\text { Model 3: } \\
\text { Parsimonious }\end{array}$ \\
\hline Intercept & $2.91(.61)^{* * *}$ & $1.74(.59)^{* *}$ & $1.74(.59)^{* *}$ \\
\hline \multicolumn{4}{|l|}{ Staff predictors (Level-1) } \\
\hline Stress at home & & $0.52(.19)^{* * *}$ & $0.60(.12)^{* * *}$ \\
\hline Supervisor Support & & $-0.27(.80)^{* *}$ & $-0.22(.80)^{* *}$ \\
\hline \multicolumn{4}{|l|}{ Controls (Level-1, fixed) } \\
\hline Race & & $0.15(.20)$ & \\
\hline Age & & $-0.00(.01)$ & \\
\hline Tenure & & $0.05(.04)$ & \\
\hline Gender & & $-0.11(.16)$ & \\
\hline Education level & & $0.05(.04)$ & \\
\hline \multicolumn{4}{|l|}{ Program predictors (Level-2) } \\
\hline Negative staffing (random effect) & & $0.62(.17)^{* *}$ & $0.45(.17)^{* *}$ \\
\hline Program resources & & $.03(.24)$ & \\
\hline \multicolumn{4}{|l|}{ Controls (Level-2, fixed) } \\
\hline Program at or below poverty level & & $0.00(.01)$ & \\
\hline \multicolumn{4}{|l|}{ Goodness of Fit } \\
\hline AIC & 299.83 & 283.55 & 258.49 \\
\hline R-Squared Level-1 & - & 0.42 & 0.41 \\
\hline R-Squared Level-2 & - & 0.55 & 0.53 \\
\hline
\end{tabular}

Note. $* p<.05, * * p<.01, * * * p<.001$ are indicators of significance level on an independent samples $t$-test 